\title{
Optimizing the Width of Strip Weeding in ARABica Coffee in Relation to CROP AGE ${ }^{1}$
}

\author{
Largura da Faixa de Controle de Plantas Daninhas em Café Arábica em Função da Idade do \\ Cafeeiro
}

\author{
ARAÚJO, F.C. ${ }^{2}$, RONCHI, C.P. ${ }^{3}$, ALMEIDA, W.L..$^{2}$, SILVA. M.A.A..$^{2}$, MAGALHÃES, C.E.O. ${ }^{2}$ and \\ GOOD-GOD, P.I.V. ${ }^{4}$
}

\begin{abstract}
The aim of this study was to determine the weed strip control (WSC) required for adequate coffee growth after transplanting. A non-irrigated, field-planted (spaced $3.80 \times 0.70 \mathrm{~m}$ ) crop was used. The experimental design was a randomized block, with four replicates. The treatments were arranged in a $9 \times 18$ split-plot design to test the WSC of 0 , $15,30,45,60,90,120,150$, and $190 \mathrm{~cm}$, which involved continuously hand-weeding at each side of the coffee row, and 18 coffee growth measurements. Multiple regression analyses were carried out relating to growth-variables as a function of both WSC and growth-evaluation times. Brachiaria decumbens was the main weed accomplishing $88.5 \%$ of the total weed dry mass. The minimum width of the WSC increases as the crop ages after transplanting. Assuming reductions of $2 \%$ and $5 \%$ in the maximum coffee growth, the recommended WSC was 75 and $52 \mathrm{~cm}$ at 4 months after transplanting (MAT), 104 and $85 \mathrm{~cm}$ at 6 MAT, 123 and $105 \mathrm{~cm}$ at 9 MAT, 134 and $116 \mathrm{~cm}$ at 12 MAT, 142 and $124 \mathrm{~cm}$ at 15 MAT, and 148 and $131 \mathrm{~cm}$ at 18 MAT, respectively. It was concluded that integrated weed management in young coffee crops must focus on the weed control only in a minimum range along coffee rows, which increases with coffee plant age, keeping natural vegetation in the inter-rows.
\end{abstract}

Keywords: Coffea arabica, competition, interference, Surinam grass, weed management, weedy periods.

\begin{abstract}
RESUMO - O objetivo deste estudo consistiu em determinar a faixa ideal de controle de plantas daninhas (FCPD) necessária para um crescimento adequado do cafeeiro após o transplantio. Foi utilizada uma lavoura não irrigada, implantada no espaçamento de 3,80 × 0,70 m, em dezembro de 2008. O delineamento experimental foi em blocos casualizados, com quatro repetições. Os tratamentos foram dispostos em um esquema de parcelas subdivididas (9 $\times 18)$ para testar as FCPDs de $0,15,30,45,60,90,120,150$ e $190 \mathrm{~cm}$, mantidas com capina continua em cada lado da linha de café, bem como seus efeitos ao longo de 18 meses após o transplantio (MAT). Efetuaram-se análises de regressão múltipla que relacionaram as variáveis de crescimento em função da FCPD e das épocas de avaliação do crescimento. A principal espécie identificada foi a poácea Brachiaria decumbens, com 88,5\% da matéria seca total das plantas daninhas. A largura minima da FCPD aumentou com a idade da cultura após o transplantio. Assumindo reduções de 2 e $5 \%$ no crescimento máximo do cafeeiro, as FCPDs recomendadas foram de 75 e $52 \mathrm{~cm}$ aos 4 MAT, 104 e $85 \mathrm{~cm}$ aos 6 MAT, 123 e $105 \mathrm{~cm}$ aos 9 MAT, 134 e $116 \mathrm{~cm}$ aos 12 MAT, 142 e $124 \mathrm{~cm}$ aos 15 MAT e 148 e $131 \mathrm{~cm}$ aos 18 meses após o transplantio, respectivamente. Conclui-se que o manejo das plantas daninhas em lavouras jovens de café deve buscar a manutenção apenas de uma faixa de controle minima na linha de plantio, cuja largura aumenta com a idade da lavoura, preservando a vegetação na entrelinha.
\end{abstract}

Palavras-chave: braquiária, Coffea arabica, competição, interferência, manejo de plantas daninhas, período de convivência.

Recebido para publicação em 20.3.2011 e aprovado em 10.10.2011.

2 Graduando em Agronomia, Universidade Federal de Viçosa - Campus Rio Paranaíba - Rod BR 354, km 310, Caixa Postal 22, 38810-000 Rio Paranaíba-MG; ${ }^{3}$ Professor, Universidade Federal de Viçosa - Campus Rio Paranaíba, <claudiopagotto@ufv.br>; ${ }^{4}$ Professor, Universidade Federal de Viçosa - Campus Rio Paranaíba, <pedro.god@ufv.br> 


\section{INTRODUCTION}

Arabica coffee (Coffea arabica) is the most important crop in Brazil because of its high economic value and the employment it generates (Chalfoun \& Reis, 2010). In addition, Brazil ranks first in world coffee production and export. Particularly in the Alto Paranaíba region, C. arabica is cultivated within $100 \%$ of its municipalities, totaling 139,403 hectares. This area yielded $17.65 \%$ of the 24,358 million bags produced by Minas Gerais Stated in 2010 (Minas Gerais, 2011).

Coffee is a perennial crop that is grown in rows and can be in production for up to 30 years. As a result of weed competition, coffee growth, yield, and quality are seriously decreased and weed control is one of the largest tasks, which entails high cost (Ronchi \& Silva, 2006; Silva $\&$ Ronchi, 2008). Crop yield losses due to weed competition varied from 24\% (Moraima et al., 2000 ) to $92 \%$ (Lemes et al., 2010). In addition to yield losses, several other harmful effects of weed competition on this crop are discussed elsewhere (Silva \& Ronchi, 2008), including weeds as an alternative host to the coffee strain of Xilella fastidiosa, which causes coffee leaf scorch (Lopes et al., 2003) and possesses a greater nutrient competitive potential than the coffee plants (Ronchi et al., 2003, 2007).

Just after transplanting in the field, young coffee plants seem to be highly sensitive to weed competition (Ronchi et al., 2003, 2007; Ronchi \& Silva, 2006; Lemes et al., 2010; Fialho et al., 2011). Such negative interference comes up because the proximity to neighboring plants (weeds) leads to resource limitations for coffee plants, especially light and nutrients. It must be stressed that the main part of the root system of an arabica coffee tree is generally concentrated in the first $0.30 \mathrm{~m}$ layer from the soil surface and is distributed in a circle around the trunk (Da Matta et al., 2009). Therefore, it may aggravate the competition effect on coffee.

To prevent weed competition, farmers sometimes decide to eliminate all weeds from the crop, even in young, widely spaced coffee plantations (upper to $3.8 \mathrm{~m}$ between rows). However, such a drastic agronomical practice is not recommended, since it requires high inputs of energy for mechanical operations and mainly because the soil exposure after weeding is not a sustainable practice. Several works have demonstrated that natural soil coverage or an introduction of cover crops between coffee rows is effective in the improvement of soil and crop characteristics (Aguilar, 2003; Shivaprasad et al., 2005; Alcântara et al., 2009).

An adequate weed control in the young coffee crops, like for other perennial crops, resumes in eliminating weed species only within a strip at both sides of coffee row, for about two years after transplanting; weeds in the inter-rows may be managed by a desiccant non-selective herbicide or by mower operations (Silva \& Ronchi, 2008). Thereby, coffee plants grow free from weed competition and weed control of the entire area is unnecessary. However, the width of WSC is randomly defined by growers, without any criteria. For example, coffee genotype and crow architecture, planting spacing, soil texture, climatic condition, weed species density, and diversity are some factors that may affect the control strip width, but they are absolutely disregarded. Other factors that also should be taken into account are the coffee plant age, since the diameter of the coffee plant canopy (and root system) progressively increases after transplantation (Da Matta et al., 2009).

Unfortunately, the availability of national and international papers regarding WSC in young coffee plantations is scarce, which suggest little importance has been given to this subject. In Brazil, an adequate width of WSC at each side of coffee row to prevent young coffee plants from weed competition were found to be $0.6 \mathrm{~m}$ (Dias et al., 2008) and $1.0 \mathrm{~m}$ (Souza et al., 2006). However, establishing a fixed weed control range irrespective of coffee plant age may be a mistake. A fixed weed control ranges of $1.0 \mathrm{~m}, 0.60 \mathrm{~m}$, and $1.0 \mathrm{~m}$ have also been respectively found for Ricinus communis (Paulo et al., 1997), Carica papaya (Bogantes $\&$ Mora, 2004), and Eucalyptus spp. (Toledo et al., 2000), which are perennial crops like coffee. However, from the works of Toledo et al. (2000), and Souza et al. (2006), and Lemes et al. (2010), which investigated weed control in both young eucalypts and coffee crops, respectively, it can be observed that the weed 
control range in young perennial crops might be variable according to the crop age.

In fact, for each time of crop life, the WSC should be large enough to prevent the establishment of weed competition with the coffee crop, but at the same time it should be minimal enough to reduce the costs of weed control and to keep the soil surface covered in the coffee inter-rows. Therefore, investigations concerning WSC variations over time are of major importance for the improvement of integrated weed management in young coffee crops.

The objective of this study was to determine the minimum WSC in the arabica coffee rows, as a function of coffee plants' age after transplantation in order to maintain the crop free from weed competition and to reduce weed control costs, as well as to protect soil on the inter-rows with natural vegetation.

\section{MATERIALS AND METHODS}

\section{Crop location and management}

The experiment was conducted with young non-irrigated field-grown Coffea arabica cv. Red Catuai IAC 144, $3.8 \times 0.7 \mathrm{~m}$ spacing, in Rio Paranaíba $\left(19^{\circ} 29^{\circ} \mathrm{S}, 46^{\circ} 55^{\circ} \mathrm{W}\right.$; 1.088 a.s.1.), south-eastern Brazil, which represents a typical Brazilian commercial crop of arabica coffee at Cerrado areas. The soil at the site was a Haplustox (Soil Survey Staff, 2010), 53\% clay, $\mathrm{pH}$ in $\mathrm{Cacl}_{2} 5.2,53 \mathrm{~g} \mathrm{dm}^{-3}$ of organic matter, $10 \mathrm{mg} \mathrm{dm}^{-3}$ of $\mathrm{P}$ (resin), 0.2, 1.2, 0.2, $0.5,7.6$, and $15.7 \mathrm{mmol} \mathrm{dm}^{-3}$ of $\mathrm{K}, \mathrm{Ca}, \mathrm{Mg}, \mathrm{Al}$, $\mathrm{H}+\mathrm{Al}$ and sum of bases, respectively, and a base saturation of $17 \%$. The soil was previously ploughed and disked twice, and coffee plantlets with four to six leaf pairs were field-planted in December 2008. For about 18 months after transplanting (MAT), the crop was managed according to conventional agronomic practices, including regular fertilization, liming, and chemical control of pest and diseases. Weed control was performed monthly accordingly to treatments (see below). Climatic conditions are of the Cwa type according to the Köppen System, but the minimum and maximum temperatures, as well as rainfall during the experimental time were collected daily at a weather station located $5 \mathrm{~km}$ from the experimental area.

\section{Experimental design and treatments}

The experimental design was in a randomized complete block, with four replicates. Plot size was one row each $5.4 \mathrm{~m}$ long, comprising eight plants, and each block was established in a coffee row. All assessments were made on the four central plants per plot. Treatments were tested in a trial using a split-plot design with nine main plot treatments, the widths of weed strip control, and 18 sub plot treatments, and the times of the coffee plant growth measurements. The control bands were: $0,15,30,45,60,90,120$, 150 , and $190 \mathrm{~cm}$ width for each side of the cultivated line. In this case, the minimum strip control represented weedy plots, including maximum ones, and the weed control onto the total area. Since coffee transplanting, weed control was applied monthly by hand-weeding to establish and keep the strip control treatments constant. In the coffee inter-rows, weeds were slashed by mechanical operations always in the flowering stages.

\section{Data collection}

Two times in 2009 (March - 3 $3^{\text {rd }}$ MAT; May $-5^{\text {th }}$ MAT) and once in 2010 (April $-16^{\text {th }}$ MAT), weeds from the inter-rows were sampled by randomly throwing a metal square $(0.3 \times 0.3 \mathrm{~m})$ twice onto each plot only for the minimum weed strip-control treatment $(0 \mathrm{~cm})$. All weeds within the metal square were collected and identified and, after counting their shoots, they were oven-dried for $72 \mathrm{~h}$, at $70{ }^{\circ} \mathrm{C}$ to determine the above ground dry biomass. Weed densities were also estimated as the number of plants per square meter. From the $1^{\text {st }}$ MAT (January 2009) until the $18^{\text {th }}$ MAT (July 2010), the growth of young coffee plants (plant height and stem diameter $-5 \mathrm{~cm}$ above ground) were measured monthly. The diameter on the bottom of the coffee plant canopy (considering the border of plant canopy projection) was also measured since $4^{\text {th }}$ MAT.

\section{Statistical analyses}

The experimental data were tested by the Lilliefors test for checking the normal assumptions of the analysis of variance. The chi square test for the goodness of fit was used. 
In addition, the skewness and kurtosis were analyzed according to Cruz (2006). The data did not need any transformation procedures and were subjected to ANOVA. Linear responsesurface models were fitted to significant statistical data using both the width of WSC and the times of plant growth measurements as independent variables. The response variables were the growth variables. Models showing high $\mathrm{r}^{2}$, with both significant parameters $(\mathrm{p}<0.05$; $t$-test $)$ and biologic logic were chosen. These statistical analyses were performed using the SAEG System version 9.1 (SAEG, 2004) and Program GENES, Quantitative Genetics and Experimental Statistics, version 2008.6.0 (Cruz, 2008).

Taking into account the fitted response surface for each growth variable, the maximum values assumed for each variable were monthly found. After that, the minimum width of WSC was estimated for different crop ages $(4,6,9,12,15$, and 18 MAT) considering reductions of $0 \%, 2 \%, 5 \%$, and $10 \%$ on that maximum young coffee plant growth.

\section{RESULTS AND DISCUSSION}

At the third month after transplanting (MAT), the main prevalent weeds in the experimental area, their density (plants $\mathrm{m}^{-2}$ ) and their percentage of shoot dry mass in relation to total weed dry mass per square meter were: Brachiaria decumbens (Surinam grass; $16.7 ; 51.4 \%$ ) and $B$. plantaginea (signal grass; $11.1 ; 20.1 \%$ ) (Figure $1 \mathrm{~A}$ ); at the $5^{\text {th }}$ MAT the main weed were: $B$. decumbens (density not available; $88.5 \%$ ) and $S$. rhombifolia $(4.0 ; 4.9 \%)$ (Figure 1B); at the $16^{\text {th }}$ MAT the main weed were: $B$. decumbens $(2.9 ; 31.5 \%)$ and $S$. glaziovii (southern sida; 1.6; 12.4\%) (Figure 1C). It must be emphasized that the shoot dry weight of $B$. decumbens, in which the percentage was already high among all weed species at $3^{\text {rd }}$ MAT, increased to almost $90 \%$ of total weed dry mass at $5^{\text {th }}$ MAT, ensuring its prevalence on the experimental area. Moreover, the aggressive growth of $B$. decumbens imposes an inter-specific competition resulting in the reductions of shoot dry mass of other weed species. For example, from $3^{\text {rd }}$ to $5^{\text {th }}$ MAT reductions on the shoot dry mass from $7.0 \%$ to $4.9 \%$ and from $4.2 \%$ to $1.3 \%$ were observed for S. rhombifolia and S. americanum, respectively. A shift in weed vegetation composition over time was also observed: some weed species disappeared (Acanthospermum australe, A. conyzoides and B. plantaginea), while other naturally occurring ones were promoted (G. parviflora, R. brasiliensis and S. glaziovii). However, neither of them reached
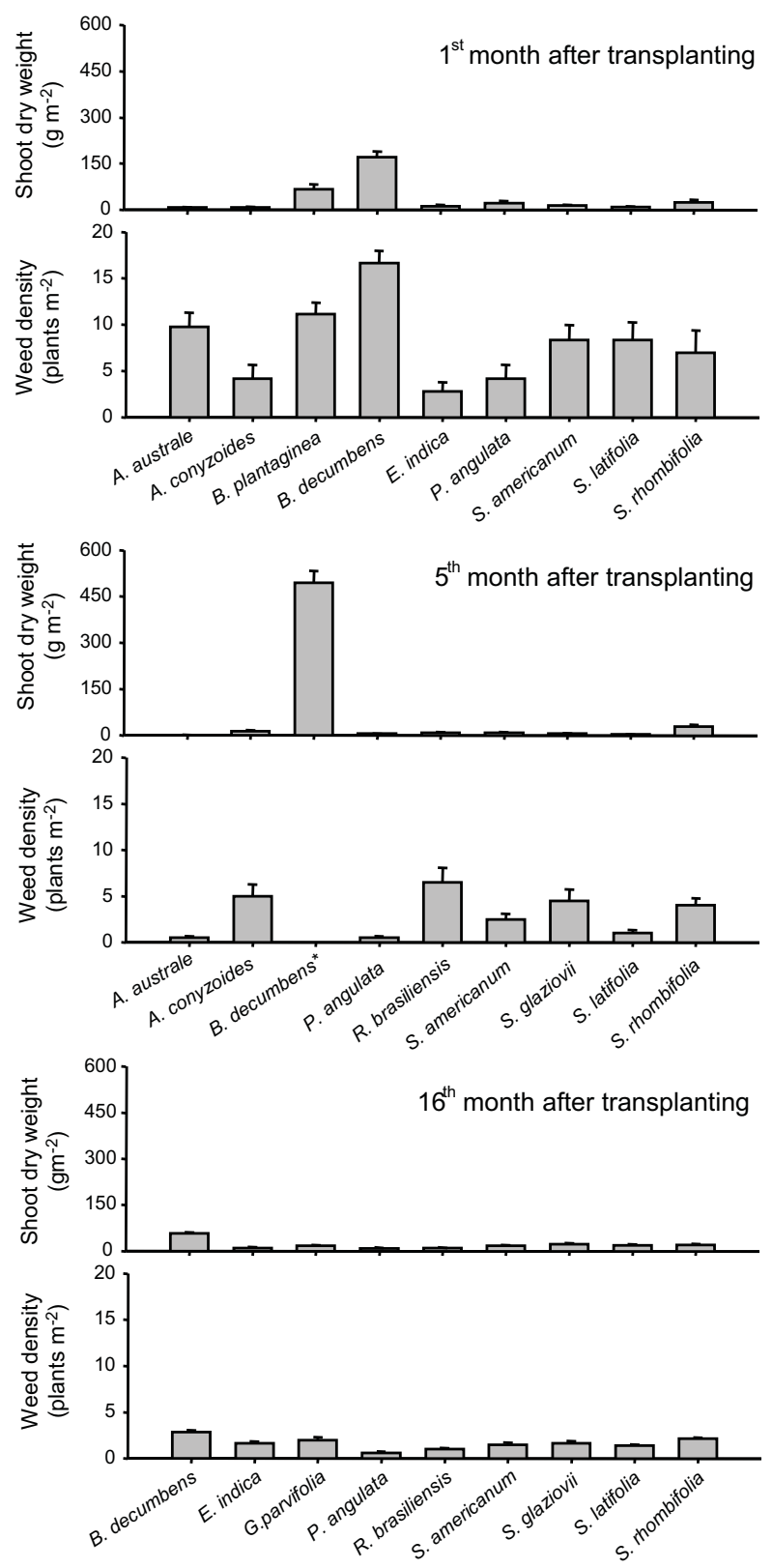

*B. decumbens - density not available. (Mean \pm standard deviation).

Figure 1 - Shoot dry weight and density of weed species from the experimental area, sampled at three different times. 
the importance level of $B$. decumbens for competition with the crop.

In several important arabica coffee growing regions of Brazil, particularly at the newer-explored Cerrado areas, coffee crops are commonly established in soil land previously used for grazing, which occurred similarly for eucalypts (Toleto et al., 2000). Since $B$. decumbens is one of the most used pasture herbage in Brazil (Drumond \& Aguiar, 2005) it became a very important weed in some coffee crop areas (Dias et al., 2004; Souza et al., 2006; Almeida et al., 2009), as observed within our experimental area. Moreover, high temperatures and abundant rainfall (Figure 2), associated with high irradiance levels occurring in the first months of coffee crop establishment in the field, altogether contributed to the growth of $B$. decumbens, since this weed species shows a $\mathrm{C}_{4}$ photosynthetic metabolism (Ueno et al., 2005; Edwards et al., 2010).

Although low water availability at some times of year (Figure 2) may aggravate weed competition and, therefore, may partially explain such a negative weed interference on crop, light, and nutrient competition with coffee and were probably the major factors determining the degree of weed competition, as has already been evidenced by Ronchi \& Silva (2006). Opposite to perennial and slow coffee plant growth just after transplanting (Da Matta et al., 2009), annual weed species show a higher growth rate than coffee (Silva \& Ronchi, 2008). Weed species like $B$. decumbens quickly developed simultaneously in leaf area and height (showing a dense canopy), factors that allow weeds to be better light competitors (Röhri \& Stützel, 2001). This means that even before reaching pre-flowering stages, when slashing operations are commonly recommended for weed control in the coffee inter-rows (Silva \& Ronchi, 2008), weed shoots can shade both the lower and medium third of the coffee plant canopy if they are allowed to grow near enough to the crop line. As a result, the photosynthetic performance of coffee plant leaves probably became light-limited and hence the carbohydrate supply for crop growth was also affected.

Adverse weed effects on coffee growth were also probably a consequence of competition mainly for essential nutrients. Recently, Ronchi \& Silva (2006) investigated weed

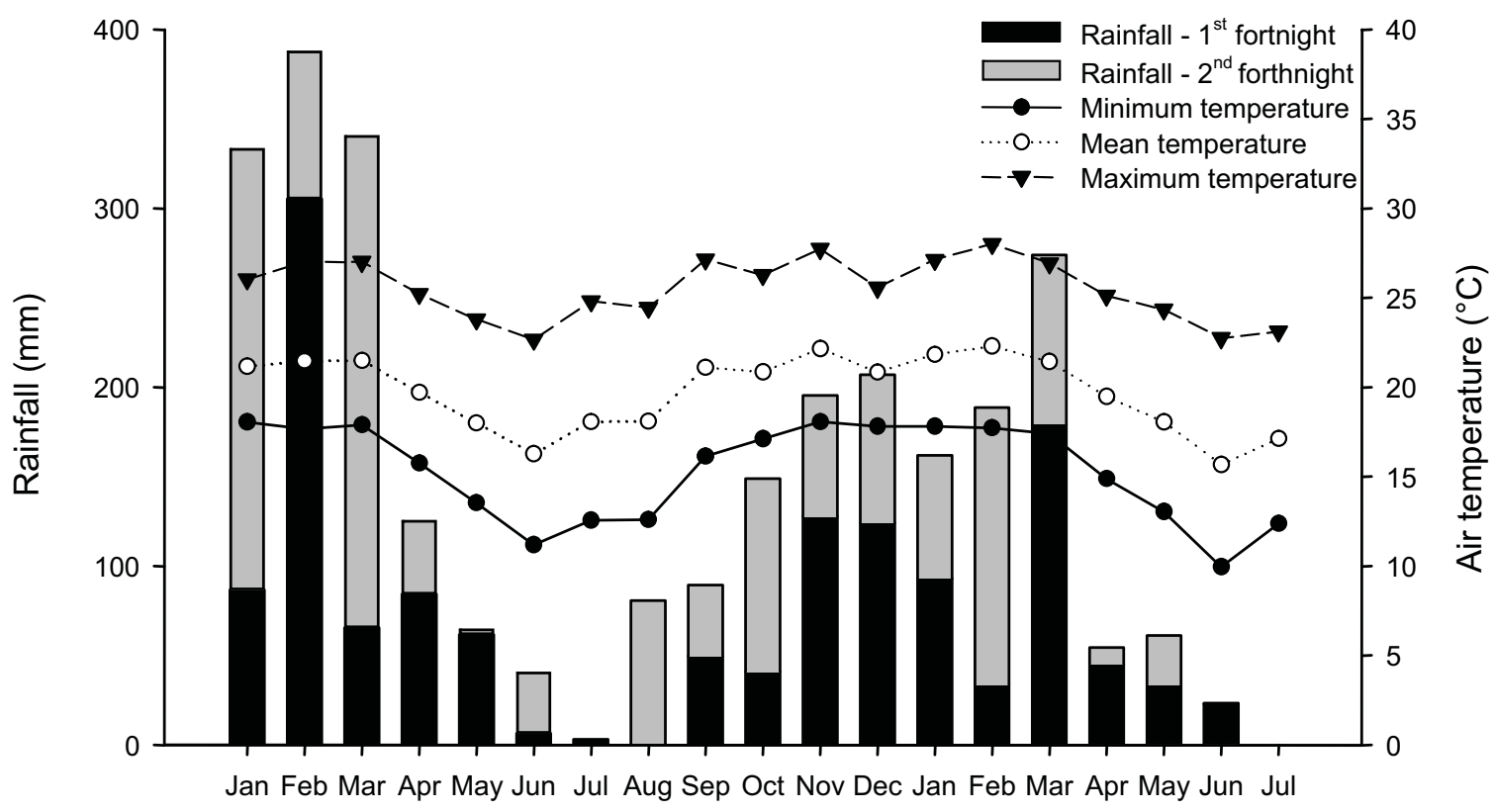

Months

Figure 2 - Air temperature and rainfall in Rio Paranaíba, from January 2009 to July 2010 recorded for the ûrst and second fortnight in each month. 
species competition on pot-grown coffee plants and found that species like S. rhombifolia had little effect on the growth of coffee plants, since only a slight decrease in all the growthcharacteristics evaluated in coffee plants was observed. On the other hand, $R$. brasiliensis and $B$. decumbens (which abundantly occurred in the present experiment) markedly reduced the growth of coffee plants. Such impaired plant growth was shown to be a result of a greater capacity of nutrient accumulation, either by weed roots (Ronchi et al., 2007) or shoots (Ronchi et al., 2003) compared to that observed for coffee.

Irrespective of weed species found on the experimental area, they were only harmful to young coffee plants when they were grown near enough to the coffee rows. Recent competition trials with young pot-grown coffee plants show that the distance between weeds and coffee plants affect coffee growth (Marcolini et al., 2009). That is the reason integrated weed management in young and perennial largespacing coffee crop resumes in eliminating weed species only within a strip at both sides of the coffee row, for about two years after transplanting (Ronchi \& Silva, 2008).

In spite of its agronomical importance, little works have been conducted around the world to precisely define the width of WSC on coffee. In Brazil, for example, Lemes et al. (2010) investigated weed interference on coffee growth and fruit production during four years after planting. Interestingly, they tested two kinds of weed control: total weed control and $0.5 \mathrm{~m}$ strip control at each side of the planting line. In the latter, the coffee yield per plant was reduced by an average of $42.6 \pm 14.7 \%$ considering three harvesting times compared to control of the total area. That indicates that $0.5 \mathrm{~m}$ strip control was not high enough to prevent weed competition at the early stages of coffee establishment. In fact, other Brazilian field-trials also demonstrated that larger strip control (from 0.6 to $1.0 \mathrm{~m}$ ) is required for an adequate coffee plant development (Dias et al., 2008; Souza et al., 2006). At both experiments, $B$. decumbens was the main weed species affecting coffee growth. Instead of fixing such a width, we evidenced that the minimum control band width must increase as the coffee plant ages after transplanting.
For all coffee growth variables (plant stem diameter, plant height, and crown diameter) significant interactions were found between the width of WSC and the age of coffee trees (Table 1). Therefore, through fitted linear response-surface models (Table 2), it was plotted for all growth variables the relation of coffee plant growth with both coffee age and width of WSC (Figure 3). In the first times after transplanting (until 2-3 MAT), weed competition does not at all or exerts very little negative effect on plant growth; as the coffee plant ages, coffee plant growth is drastically reduced if any weed-control practice is employed. However, an adequate coffee growth is ensured along 18 MAT if a minimum WSC is applied to coffee rows (Figure 3). It must be emphasized that as the coffee plant ages WSC must be progressively greater to prevent weed competition, and thereby to enable the coffee to grow properly.

Taking into account the regression equations in Table 2 , the minimum WSC values required for adequate plant growth were estimated, at different months after transplanting, considering reductions of $0 \%, 2 \%, 5 \%$, and $10 \%$ in the growth of each variable (Table 3) compared to the maximum growth observed for them (also obtained by Table 2 - equations). An average of WSC, considering all the variables, was used for discussion (Table 3; Figure 3D). For example, When a $2 \%$ reduction is allowed to occur in the potential coffee growth, the minimum width of WSC was $75,104,123,134,142$, and $148 \mathrm{~cm}$ at $4,6,9,12,15$, and $18 \mathrm{MAT}$, respectively (Table 3, Figure 3 ). If a greater percentage of growth reduction is assumed $(5 \%$ or $10 \%$ ), lower WSC is needed (Table 3 , Figure 3D). Opposite to Dias et al. (2004) and Souza et al. (2006), who recommended a fixed WSC for young field-planted coffee crops, it is reasonable that WSC is progressively increased as the coffee plant ages. According to this study, the width of WSC must increase quickly until 7 to $9 \mathrm{MAT}$, and then it continues to rise but at lower rates of approx. $2-3 \mathrm{~cm}$ per month (Figure 3D).

Our findings were only possible because we applied an adequate statistical approach to the data. Using the method presented herein on the data presented by Souza et al. (2006) reveals a correspondence between these findings. 
Table 1 - Effects of weed strip control on the stem diameter, plant height, and diameter of the coffee plant canopy evaluated at 18 months after transplanting

\begin{tabular}{|l|c|c|c|c|c|}
\hline \multirow{2}{*}{ Source of variation } & \multirow{2}{*}{ d.f. } & \multicolumn{2}{c|}{ Mean square } & \multirow{2}{*}{ d.f. } & Mean square \\
\cline { 3 - 5 } \cline { 3 - 5 } & & Stem diameter & Plant height & & Shoot diameter \\
\hline Blocks & 3 & $28.876^{* *}$ & $721.187^{* *}$ & 3 & $973.020^{* *}$ \\
\hline Weed strip control range $(A)$ & 8 & $1225.841^{* *}$ & $7707.078^{* *}$ & 8 & $31950.510^{* *}$ \\
\hline Error $(a)$ & 24 & 27.750 & 345.430 & 24 & 502.432 \\
\hline Growth evaluation time $(B)$ & 17 & $1227.311^{* *}$ & $13153.950^{* *}$ & 14 & $16853.780^{* *}$ \\
\hline$A B$ & 136 & $45.646^{* *}$ & $291.178^{* *}$ & 112 & $785.747^{* *}$ \\
\hline Error $(b)$ & 459 & 2.189 & 13.235 & 378 & 28.198 \\
\hline Coef. variation $(\%)$ - split-plot & & 10.32 & 6.81 & & 9.06 \\
\hline Coef. variation $(\%)$ - plot & & 36.76 & 34.79 & & 38.24 \\
\hline
\end{tabular}

$F$ - test significant at $* * \mathrm{p}<0.01$.

Table 2 - Regression equations and correlations for the coffee plant growth variables as a function of both weed strip control (X, in centimeters) and the coffee plant's age (Z, in months after transplanting). See Figure 3 for the plotted equations

\begin{tabular}{|c|c|c|}
\hline Variables & Regression equations & $\mathrm{r}^{2}$ \\
\hline Stem diameter & $\begin{aligned} \hat{\mathrm{Y}}= & 6.11238-0.0382 * * \mathrm{X}+0.00014 * \mathrm{X}^{2}+0.30053 * \mathrm{Z}-0.0084^{\mathrm{ns}} \mathrm{Z}^{2}+0.01462 * * \mathrm{XZ} \\
& -0.00006 * \mathrm{X}^{2} \mathrm{Z}+0.00021 * * \mathrm{XZ}^{2}\end{aligned}$ & 97.93 \\
\hline Plant height & $\begin{aligned} \hat{\mathrm{Y}}= & 21.1389-0.0406^{\mathrm{ns}} \mathrm{X}+0.00004^{\mathrm{ns}} \mathrm{X}^{2}+2.61091 * * Z-0.07163 * * \mathrm{Z}^{2}+0.03058^{* *} \mathrm{XZ} \\
& -0.0001 * * \mathrm{X}^{2} \mathrm{Z}+0.00056^{*} \mathrm{XZ}^{2}\end{aligned}$ & 95.46 \\
\hline Shoot diameter & $\begin{aligned} \hat{\mathrm{Y}}= & 5.59076-0.30448 * \mathrm{X}+0.00055^{\mathrm{ns}} \mathrm{X}^{2}+3.02511 * * \mathrm{Z}-0.12403 * * \mathrm{Z}^{2}+0.08934 * * \mathrm{XZ} \\
& -0.00023^{* *} \mathrm{X}^{2} \mathrm{Z}\end{aligned}$ & 95.00 \\
\hline
\end{tabular}

$t$ - Test at ${ }^{*} \mathrm{p}<0.05$ and ${ }^{* *} \mathrm{p}<0.01$ was applied to the equation parameters. ${ }^{\text {ns }}$ for $\mathrm{p}>0.05$.

Hence, they probably would have stated, four years ago, that WSC must increase as the coffee plant ages, instead of recommending the range of $100 \mathrm{~cm}$ as a fixed WSC during about two years after transplanting.

As has already been shown (Figure 3, Tables 2 and 3), coffee growth increases as WSC rises, but careful interpretation of the data shows that maximum coffee plant growth was reached, for each time of the evaluation (or for different coffee plant age), at a WSC lower than the largest one $(190 \mathrm{~cm})$ that was tested; above such a critical WSC value, the coffee growth was slightly reduced. For example, at 6,12 , and 18 MAT, coffee growth was decreased at WSC greater than the critical value of 104, 134, and $148 \mathrm{~cm}$, respectively (Table 3; $\%$ reduction). Drastically eliminating weed species in the inter-rows, but not the weed competition in the coffee rows, may explain such a negative effect. Hence, we believe that the maintenance of natural weed coverage in the center of coffee inter-rows (always when WSC is not too large) may have favored edaphoclimatic conditions for the improvement of coffee plant growth. In fact, several works indicate many benefits of cover crops management in the inter-rows of coffee plantations (Aguilar et al., 2003; Shivaprasad et al., 2005; Ronchi et al., 2007; Alcântara et al., 2009). Moreover, the cost of weed control may be diminished if it is applied only to the minimum WSC. It must be registered that such a discrete reduction of coffee growth, when an excessive width of WSC (or weed control of the total area) is used, also occurred in the experiment of Dias et al. (2008). However, the results appeared different only due to the use of different statistical methods.

The results thus suggests that integrated weed management in coffee crops should adopt variable WSC as coffee plant ages, without allowing weed control of the total area. Moreover, it is believed that the diameter of coffee plant canopy (DCC) is a better criterion for correctly establishing the width of WSC at both sides of the coffee rows, for any coffee plant 

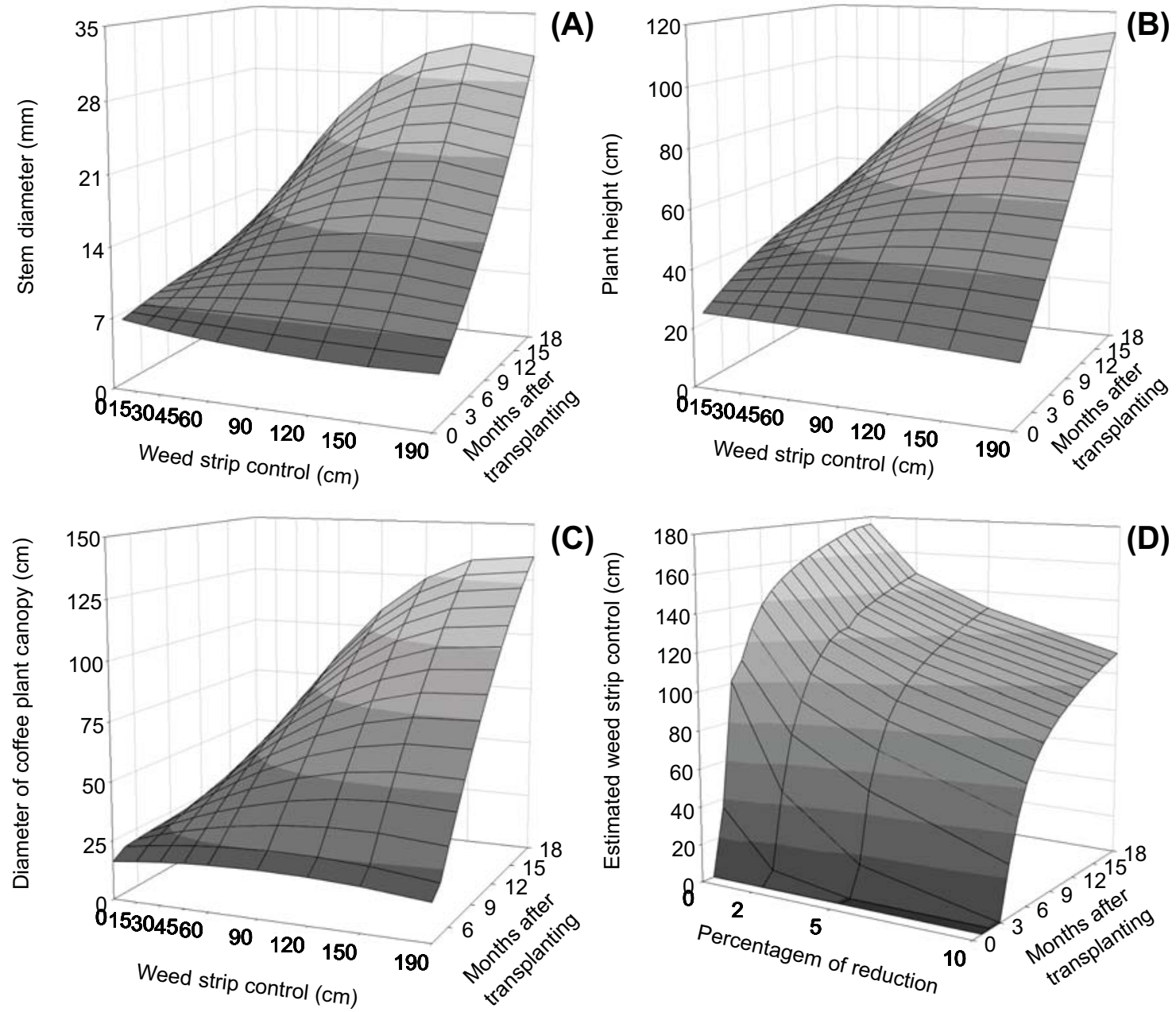

Figure 3 - Coffee plant growth as a function of both the weed strip control and coffee plants' age in the months after transplanting: stem diameter (A), plant height (B) and diameter of the coffee plant canopy (C), and estimated weed strip control values at different months after transplanting, considering reductions of $0 \%, 2 \%, 5 \%$, and $10 \%$ in the maximum growth of each variable (D). For regression models, see Table 1.

Table 3 - Minimum weed strip control values (in centimeters) at different months after transplanting, estimated considering reductions of $0 \%, 2 \%, 5 \%$, and $10 \%$ in the maximum growth observed for each variable. The average values were used in the discussion

\begin{tabular}{|c|c|c|c|c|c|c|c|c|c|c|c|c|}
\hline \multirow{3}{*}{$\begin{array}{c}\text { Growth } \\
\text { variables }\end{array}$} & \multicolumn{12}{|c|}{ Estimated weed strip control at different months after transplanting } \\
\hline & $4^{\text {th }}$ & $6^{\text {th }}$ & $9^{\text {th }}$ & $12^{\text {th }}$ & $15^{\text {th }}$ & $18^{\text {th }}$ & $4^{\text {th }}$ & $6^{\text {th }}$ & $9^{\text {th }}$ & $12^{\text {th }}$ & $15^{\text {th }}$ & $18^{\text {th }}$ \\
\hline & \multicolumn{6}{|c|}{$0 \%$ reduction } & \multicolumn{6}{|c|}{$2 \%$ reduction } \\
\hline Stem diameter & 119 & 130 & 138 & 144 & 150 & 156 & 77 & 98 & 110 & 118 & 124 & 130 \\
\hline Plant height & 126 & 146 & 163 & 175 & 186 & 190 & 81 & 105 & 125 & 139 & 150 & 160 \\
\hline Shoot diameter & 90 & 140 & 164 & 174 & 179 & 182 & 67 & 110 & 135 & 145 & 150 & 154 \\
\hline \multirow[t]{2}{*}{ Mean } & 111.2 & 138.3 & 155.0 & 164.5 & 171.7 & 175.8 & 75.1 & 104.3 & 123.4 & 133.8 & 141.6 & 148.9 \\
\hline & \multicolumn{6}{|c|}{$5 \%$ reduction } & \multicolumn{6}{|c|}{$10 \%$ reduction } \\
\hline STD & 53 & 79 & 94 & 102 & 109 & 115 & 26 & 58 & 75 & 85 & 92 & 98 \\
\hline PLH & 55 & 81 & 103 & 118 & 129 & 139 & 26 & 55 & 78 & 94 & 106 & 116 \\
\hline DCC & 47 & 93 & 119 & 128 & 134 & 138 & 28 & 74 & 100 & 110 & 115 & 120 \\
\hline Mean & 51.6 & 84.6 & 105.0 & 116.0 & 124.1 & 130.6 & 26.4 & 62.3 & 84.3 & 96.0 & 104.3 & 111.1 \\
\hline
\end{tabular}


age: firstly, it progressively increases (dynamic variable) as the coffee plant ages; secondly, it is easily measured under field-conditions; and thirdly because we found, for different coffee plant ages, that adequate coffee growth was reached (for all the cases) only when WSC supplanted (or at least was the same) the DCC (Figure 4). Therefore, the agronomical recommendations of recent decades (Sánchez, 1991; Silva \& Ronchi, 2008) for controlling weeds only just below the projection of the coffee plant canopy, to prevent weed competition, may be equivocated. According to the results, the following equation is now proposed, 'WSC $=\mathrm{DCC} * f$ ' for the proper estimation of WSC. In all cases, $f$-value must be equal or greater than one $(f \geq 1)$. Probably, $f$-values between 1 and $3(1 \leq f \leq 3)$ will be reasonable. In fact, a negative exponentialresponse of $f$-values as the coffee plant ages was observed: higher $f$-values $(\sim 3.0)$ for young coffee crops (about 3 to 6 MAT), which decreases and stabilizes nearly the minimum value $(f \sim 1)$ for crops older than 12 MAT (Figure 4). In any case, new field-competition experiments are necessary to properly define the $f$-values, since it may be affected by both occurring weed species and adopted integrated weed management methods.

Many growers are indiscriminately using $B$. decumbens in the whole coffee inter-rows as planted ground cover grass, as described in Alcântara \& Silva (2010). Sometimes, before mower operations, they allowed this weed to grow exuberantly as high as the young coffee plant canopy. They aim to add biomass on the soil surface for soil moisture conservation and nutrient recycling. In fact, a larger turnover of organic matter when maintaining ground cover vegetation might improve long-term soil fertility (Aguilar et al., 2003). Although such a practice may bring advantages for the crop, one must be careful if the WSC is not precisely defined; as demonstrated in this trial, $B$. decumbens may permanently impair coffee growth.

It was concluded that integrated weed management in young coffee crops must focus on weed control only in a minimum range along the coffee rows, which must increase with the coffee plant's age. Since the WSC values indicated in the text are followed by growers, coffee crops will grow free from weed interference and simultaneously the soil will

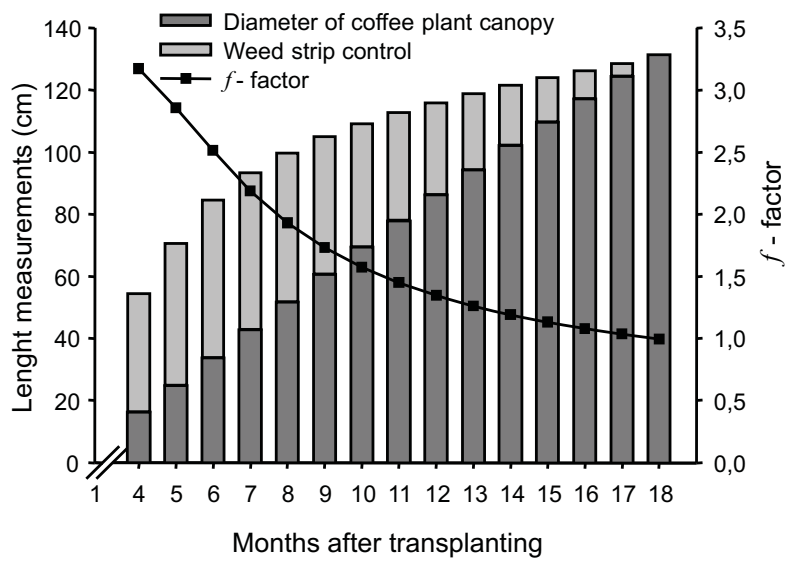

( $f$-factor was estimated as the relation of WSC to DCC).

Figure 4 - Evolution of the diameter of the coffee plant canopy (DCC) and recommended weed strip control (WSC) assuming a $5 \%$ reduction on coffee growth, 18 months after transplanting, and their relation with the $f$-factor.

be protected in the inter-rows by naturally occurring weeds.

\section{ACKNOWLEDGMENTS}

This study was funded by the Minas Gerais State Research Foundation, Brazil (Grant CAG 13 APQ-00028-08). We thank the farmer, Mr. A. S. Ribeiro, for kindly allowing us to use his coffee crop field.

\section{LITERATURE CITED}

AGUILAR, V. et al. Weed vegetation response to chemical and manual selective ground cover management in a shaded coffee plantation. Weed Res., v. 43, n. 1, p. 68-75, 2003.

ALCÂNTARA, E. N. et al. Métodos de controle de plantas daninhas no cafeeiro afetam os atributos químicos do solo. Ci. Rural, v. 39, n. 3, p. 749-757, 2009.

ALCÂNTARA, E. N.; SILVA, R. A. Manejo do mato em cafezais. In: REIS, P. R.; CUNHA, R. L. (Eds.). Café Arábica do Plantio à Colheita. Lavras: Epamig, 2010. p. 519-572.

ALMEIDA, W. L. et al. Ocorrência de plantas daninhas em lavoura recém transplantada e não irrigada de café no Alto Paranaíba-MG. In: CONGRESSO BRASILEIRO DE PESQUISAS CAFEEIRAS, 35., 2009, Araxá. Livro de resumos... Varginha: MAPA/PROCAFÉ, 2009.

BOGANTES, A.; MORA, E. Factibilidad técnica de la utilización de cobertura vegetal en papaya (Carica papaya L.) mediante la aplicación localizada de herbicidas. Agron.

Mesoam., v. 15, n. 2, p. 193-199, 2004. 
CHALFOUN, S. M.; REIS, P. R. História da cafeicultura no Brasil. In: REIS, P. R.; CUNHA, R. L. (Eds.). Café arábica: do plantio à colheita. Lavras: Epamig, 2010. v. 1. p. 21-86.

CRUZ, C. D. Programa GENES: estatística experimental e matrizes. Viçosa, MG: Universidade Federal de Viçosa, 2006. 285 p.

DA MATTA, F. M. et al. Coffee: environment and crop physiology. In: DA MATTA, F. M. (Org.). Ecophysiology of tropical tree crops. Hauppauge: Nova Science Publishers, 2009. v. 1. p. 181-216.

DIAS, G. F. S.; ALVES, P. L. C. A.; DIAS, T. C. S. Brachiaria decumbens suppresses the initial growth of Coffea arabica. Sci. Agric., v. 61, n. 6, p. 579-583, 2004.

DIAS, T. C. S.; ALVES, P. L. C. A.; LEMES, L. N. Faixas de controle de plantas daninhas e seus reflexos na produção do cafeeiro. Científica, v. 36, n. 1, p. 81-85, 2008.

DRUMOND, L. C. D.; AGUIAR, A. P. A. (Eds.). Irrigação de pastagem. Uberaba: LCD Drumond, 2005. 210 p.

EDWARDS, E. J. et al. $\mathrm{C}_{4}$ Grasses Consortium. The origins of $\mathrm{C}_{4}$ Grasslands: integrating evolutionary and ecosystem science. Science, v. 328, n. 5978, p. 587-591, 2010.

FIALHO, C. M. T. et al. Interferência de plantas daninhas sobre o crescimento inicial de Coffea arabica.

Planta Daninha, v. 29, n. 1, p. 137-147, 2011.

LEMES, L. N. et al. Weed interference on coffee fruit production during a four-year investigation after planting. Afr. J. Agric. Res., v. 5, n. 10, p. 1138-1143, 2010.

LOPES, S. A. et al. Weeds as alternative hosts of the citrus, coffee, and plum strains of Xylella fastidiosa in Brazil. Plant Dis., v. 87, n. 5, p. 544-549, 2003.

MARCOLINI, L. W. et al. Effect of the density and of the distance of Brachiaria decumbens staff on the initial growth of Coffea arabica L. seedlings. Coffee Science, v. 4, n. 1, p. 11-15, 2009.

MORAIMA, G. S. et al. A contribution to determine critical levels of weed interference in coffee crops of Monagas state, Venezuela. Bioagro, v. 12, n. 3, p. 63-70, 2000.

PAULO, E. M.; KASAI, F. S.; FILHO, A. S. Efeitos da largura da faixa de capina na cultura da mamona. Bragantia, v. 56, n. 1, p. 145-153, 1997.

RÖHRIG, M.; STÜTZEL, H. A model for light competition between vegetable crops and weeds. Eur. J. Agron., v. 14, n. 1, p. 13-29, 2001.
RONCHI, C. P.; SILVA, A. A. Effects of weed species competition on the growth of young coffee plants. Planta Daninha, v. 24, n. 3, p. 415-423, 2006.

RONCHI, C. P.; TERRA, A. A.; SILVA, A. A. Growth and nutrient concentration in coffee root system under weed species competition. Planta Daninha, v. 25, n. 4, p. 679-687, 2007.

RONCHI, C. P. et al. Acúmulo de nutrientes pelo cafeeiro sob interferência de plantas daninhas. Planta Daninha, v. 21, n. 2, p. 219-228, 2003.

SÁNCHEZ, F. L. E. Lãs malezas em los cafetales: recomendaciones prácticas para su control. Fonaiap Divulga, v. 9, p. 18-27, 1991.

MINAS GERAIS. Secretaria de Estado de Agricultura, Pecuária e Abastecimento De. Dados do Agronegócio produção agrícola: café. Disponível em: < http:// www.agricultura.mg.gov.br/dados-do-agronegocio > . Acesso em: 8 fev. 2011.

SHIVAPRASAD, P. et al. Influence of soil cultivation methods in young coffee on soil moisture, weed suppression and organic matter. J. Coffee Res., v. 33, n. 1-2, p. 1-14, 2005.

SILVA, A. A.; RONCHI, C. P. Manejo e controle de plantas daninhas em café. In: VARGAS, L.; ROMAN, E. S. (Eds.). Manual de manejo e controle de plantas daninhas. Bento Gonçalves: Embrapa Uva/Vinho, 2008. p. 417-476.

\section{SISTEMA DE ANÁLISES ESTATÍSTICAS E GENÉTICAS}

- SAEG. Versão 9.0. Viçosa: Fundação Arthur Bernardes, 2004.

SOIL SURVEY STAFF. Keys to soil taxonomy. 11.ed. Washington: USDA-Natural Resources Conservation Service, 2010.

SOUZA, L. S. et al. Efeitos das faixas de controle do capimbraquiária (Brachiaria decumbens) no desenvolvimento inicial e na produtividade do cafeeiro (Coffea arabica).

Planta Daninha, v. 24, n. 4, p. 715-720, 2006.

TOLEDO, R. E. B. et al. Efeitos da faixa de controle do capim-braquiária (Brachiaria decumbens) no desenvolvimento inicial de plantas de eucalipto. Planta Daninha, v. 18, n. 3, p. 383-393, 2000.

UENO, O.; YOSHIMURA, Y.; SENTOKU, N. Variation in the activity of some enzymes of photorespiratory metabolism in c 4 grasses. Ann. Bot., v. 96, n. 5, p. 863-869, 2005. 